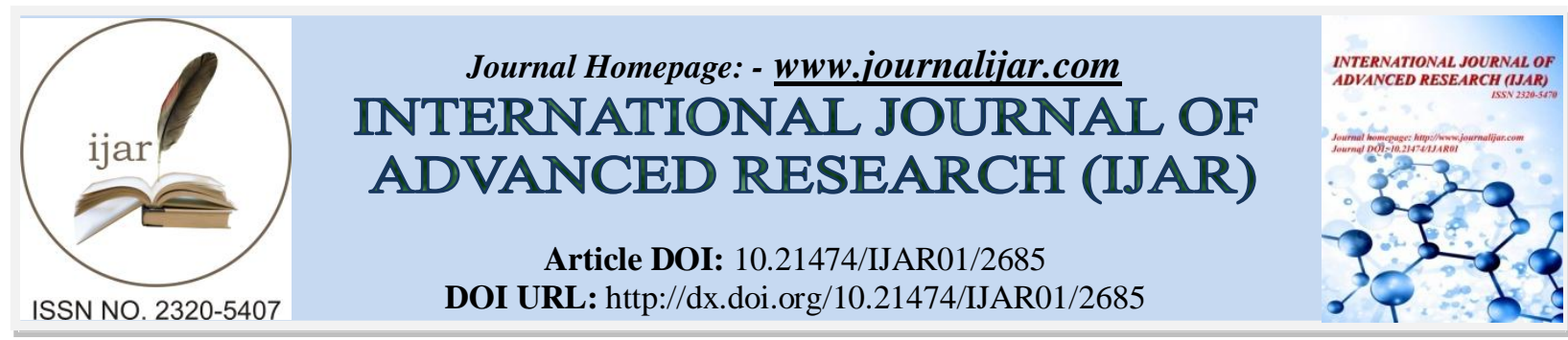

RESEARCH ARTICLE

\title{
INFLUENCE OF SOCIAL MEDIA ON ACADEMIC PERFORMANCE OF STUDENTS IN ENUGU STATE UNIVERSITY OF SCIENCE AND TECHNOLOGY (ESUT).
}

Loretta Chika Ukwuaba (Ph.D) ${ }^{1}$, Catherine Nkiru Elechi (Ph.D $)^{2}$ and Gertrude Nkechi Okenwa (Ph.D $)^{2}$.

1. Department of Adult and Continuing Education.

2. Department of Educational Management (ESUT), Agbani.

\section{Manuscript Info}

Manuscript History

Received: 31 October 2016

Final Accepted: 01 December 2016

Published: December 2016

\section{Abstract}

The study examined perception of student on influence of use of social media on academic performance of students in Enugu State University of Science and Technology. One research question and one hypothesis guided the study. A survey research design was adopted for the study. Purposeful sampling technique was used to sample 160 students, 80 females and 80 males third year students of Faculty of Education. The instrument for data collection was a 10iteme questionnaire developed by the researcher. The questionnaire was validated by three experts in the fields of education and a reliability of 0.79 was obtained using Cronbach alpha method of determining internal consistency of instrument. The research question was answered using mean and the hypothesis was tested at 0.05 level of significance using t-test statistic. The result indicated that students agreed that use of social media influence students academic performance and there is no significant difference in the mean response of female and male students on the influence of social media on academic performance. Encouraging students to spend more time on academic activities, provision of entertaining and amusement centres in the universities among others were some of the recommendation made.

Copy Right, IJAR, 2016,. All rights reserved.

\section{Introduction:-}

Social environment involves man's interaction and relationship with people in the society where he found himself. It include the culture that the individual is educated or live in and the people and institutions with whom they interact. The interaction may be in person or through communication media. Communication is a basic human need and for this reason man has always found a means of meeting this needs either through interpersonal or mass communication (Kirschner and Aryn, 2010). The media as an umbrella term for various means of communication has become an integral part of human life around the world. The earliest form of personal media, speech and gesture had the benefit of being easy to use and did not necessarily need complex technology. Presently, the world has become a global village with the invention of various forms of social media for interaction.

Social media is a form of electronic communication which facilitates interaction based on certain interest and characteristics. Business dictionary described social media as primarily internet or cellular phone-based applications and tools to share information among people. Social media include popular networking websites like facebook and twitters as well as bookmarking sites. It involves blogging and forums and any aspect of an interactive presence 
which allow individuals the ability to engage in conversation with one another, often as a discussion over a particular blog, news, article or events. (www.businessdictionary.com/socia/media.html).

Social networking cites have created a new social dimension where individuals can increase their social awareness by keeping in touch with old friends, making new friends, dispensing new ideas or product and gathering information in other aspect of everyday life. It is on record that at least 16 million Nigerians visit social media platform every month with a good number of them being young people (Face book statistic, 2016). The internet is more that just a means of seeking information. People discovered that the internet can connect with other people for business or commercial purpose to make new friends or to re-awaken old friends and long lost relation.

The popularity of social media such as face book, twitters, blade berry, yahoo messenger, yahoo.mail, instagram, whatsapp etc continues to grow providing people with opportunities to interact through them (Hinz, Skiera, Barrot and Beckers, 2011). People now make use of these opportunities given through social networking to interact with friends and family that are very far from them by spending significant time on social media (Schulz, Schola and Skiera, 2014). For instance two out of every Nigerian student is active on face book and spend an average more than two hours a day on facebook.

A student is a person who is learning at a college or university (www.dictionary.cambridge.org). Schools, colleges and universities have no worth without students. Students are the most essential asset for any educational institution. The social and economic development of the country is directly linked to students academic performance. Academic performance is the outcome of educational goals. Woolfolk (2007) sees academic performance as performance outcome that indicate the extent to which a person has accomplished specific goals that were the focus of activities in instructional environment, specifically in school, college and university. It is generally referred to as how well a student is accomplishing his or her task and studies. Students academic performance plays an important role to producing the best quality graduates from universities who will become great leaders of tomorrow.

University life can be stressful although it is undoubtedly one of the most memorable experiences of one's life. It represent a critical developmental period for both adolescents and young adult students in the universities enjoying academic freedom which allows them to engage in many social activities within and outside the school environment. This academic freedom in most cases are being abused by students limiting them to fewer time of study, which in turn will have negative effect on their success. Junco (2012) posits that time students spend on social network sites and video games is regularly associated with college GPA.

Social media is the order of the day and as a student if you are not in any social media like whatsapp, blackberry, messenger, twitter, facebook, instagram, just to mention but a few, you are seen as old fashioned. Students get carried away by things they see on television and social media that they loose focus on their purpose in school. Studies has shown that an average student both male and female spend more time watching and surfing the net than any other activity. Surfing the internet while studying results in multi-tasking which decreases performance and efficiency because it reduces concentration to study well (Scott, 2000).

These forms of media use have an impact on students' academic performance. Student who spend more time engaging in these forms of media use end up not completing their school assignment and not attending to lectures (Jacobsen \& Forste, 2011). These students end up having low academic confidence and pay less attention during lectures. Jacobsen \& Forste (2011) stated further that some form of media use may even be so appealing that they are chosen as alternative to attending classes. Thompson \& Austin (2003) posit that television viewing AND aggressive violent watching on television displaces or takes time away from intellectually demanding activities such as doing assignment and studying which have negative effects on grades and academic performance. Watching television leads to mental laziness (Thompson \& Austin, 2003). When students watch highly information programs such as news programs and documentaries they have a greater opportunity to increase knowledge and learn, but when they watch mostly low informational programs such as fast-action shows, cartoon or music video an opportunity for a detrimental academic impact is increased.

In Enugu State University of Science and Technology, students are faced with lack of entertainment, amusement centres which make an average student to resort to social media use. This invariable may affect their study. This 
study therefore sought to determine students perception on the influence of social media on their academic performance.

\section{Research Question:-}

What is the perception of students on the influence of social media on their academic performance.

\section{Null Hypothesis:-}

There is no significant difference in the mean rating of male and female students regarding how social media influence academic performance of students in ESUT.

\section{Research Method:-}

The research design used for the study was descriptive survey research. A purposeful sampling technique was adopted to sample 160 ( 80 male $\& 80$ female) $3^{\text {rd }}$ year students of Faculty of Education ESUT for the study. The instrument used for data collection was a 10-itemed questionnaire validated by three experts in the field of Education (one from Measurement and Evaluation and two from Adult and Continuing Education). The instrument has a response option of Strongly Agree (SA), Agree (A) Disagree (D) Strongly Disagree (SD). A reliability estimate of 0.79 was obtained for the instrument. 160 copies of the instrument was distributed to the respondents with the aid of four research assistants trained by the researcher. A $100 \%$ return rate was achieved.

Mean statistics was used to answer the research question, while the hypothesis was tested using t-test statistics at 0.05 level of significance. Any mean of 2.50 and above was accepted as an indication that social media influence students' academic performance and vice versa. When the t-calculated is equal to or less than the t-critical, the null hypothesis was accepted, otherwise, not accept.

\section{Results:-}

Table 1:- Mean rating of students (female \& male) on the influence of social media on academic performance of students in ESUT.

\begin{tabular}{|c|c|c|c|c|c|}
\hline \multirow{3}{*}{$\begin{array}{l}\text { No: } \\
\text { S/N }\end{array}$} & 160 & & & & \\
\hline & \multirow[b]{2}{*}{ Social Media Use: } & \multicolumn{2}{|c|}{ Female } & \multicolumn{2}{|c|}{ Male } \\
\hline & & $\mathbf{X}$ & SD & $\mathbf{X}$ & SD \\
\hline 1. & is multi-tasking which reduces concentration. & 3.20 & 0.82 & 2.81 & 0.99 \\
\hline 2. & interest students than studying. & 2.68 & 1.01 & 2.61 & 1.02 \\
\hline 3. & prevent students from attending to lectures & 2.61 & 1.00 & 2.53 & 1.03 \\
\hline 4 & make students loose focus on their purpose in school. & 2.34 & 1.05 & 2.21 & 1.07 \\
\hline 5 & interfere with students sleep. & 3.00 & 0.90 & 3.12 & 0.85 \\
\hline 6 & interfere with their preparation for class. & 2.73 & 1.00 & 2.81 & 0.98 \\
\hline 7 & $\begin{array}{l}\text { make students loose sense of objectivity and creativity due to already } \\
\text { stored information on the internet. }\end{array}$ & 3.13 & 0.88 & 2.62 & 1.01 \\
\hline 8 & take students time for carrying out home works and assignments. & 2.87 & 0.99 & 2.56 & 1.08 \\
\hline 9 & make students spend more time chatting than reading books. & 2.90 & 0.93 & 2.88 & 1.01 \\
\hline 10 & lead to mental laziness & 2.83 & 0.96 & 3.01 & 0.89 \\
\hline & Mean & 2.82 & & 2.71 & \\
\hline & Grand Mean & & 2.76 & & \\
\hline & Grand Standard Deviation & & 0.96 & & 0.99 \\
\hline
\end{tabular}

Table 1 indicate that the male and female respondents had high mean items 1, 2, 3, 4, 6, 7, 8, 9 and 10 respectively, an indication that they agree that social media influence students' academic performance in Enugu State University of Science and Technology (ESUT). On the other hand, a low mean for item 4 which indicate that the use of social media make student loose focus of their purpose in school.

However, a grand mean of 2.76 was obtained from the 10 items an indication that the students agreed that use of social media influence academic performance of students in Enugu State University of Science and Technology (ESUT). 
Table II:- t-test of difference between the mean rating of female and male students on the influence of social media on academic performance of students in ESUT.

\begin{tabular}{|l|c|c|c|c|c|c|c|}
\hline \multicolumn{1}{|c|}{ Gender } & $\mathbf{n}$ & $\mathbf{X}$ & SD & df & t.cal & t.crit. & Decision \\
\hline Female & 80 & 2.82 & 0.96 & & & & \\
\cline { 1 - 5 } Male & 80 & 2.71 & 0.96 & 158 & 0.71 & 1.96 & Accept \\
\hline
\end{tabular}

Table II indicated that the calculated t-value at $0.05 \%$ level of significance and 158 degree of freedom is 0.71 , while the critical value under the same condition is 1.96. since the calculated value is less than the critical table value, the null hypothesis is therefore not rejected. This is means that there is no significant difference between the mean rating of female and male students regarding the influence of social media on academic performance of students in Enugu State University of Science and Technology (ESUT).

\section{Discussion of Findings:-}

Results from the data analysis reveals that the use of social media influence academic performance of students in ESUT. Social media is multitasking and reduces students concentration in class and interest, in reading. This is in line with the earlier opinion of Scott (2000) and Jacobsen and Porste (2011) that the use of social media reduces concentration in class and lead to poor study habit. Jacobsen and Portse (2011) buttressed this notion when they declared that some of these social media sites are so appealing that some students choose it as alternative to attending classes and studying. They end up not completing assignment and attending lectures or pay less attention to lectures. The result also revealed that students spend so much time on social media, thus interfering with their sleep and to Thompson and Austin (2003), it may result to mental laziness.

This implies that students use of social media may invariably influence their academic performance. This is because it may take much of their study time and influence attendance to lectures and other academic activities.

On the other hand, students did not agree with an earlier notion of Scott (2000) that the use of social media make students loose focus of their purpose in school. This implies that in as much students use social media, they still have focus on their purpose in school, but accepted that the use of social media is a distraction toward this purpose.

The result of the hypothesis indicate that there is no significant difference between male and female responses on the influence of social media on academic performance of students. This result may be based on the fact that most students (female and male) interact with friends and family members on social media. It is a common belief among students that it is only "old fashioned students" that do not use social media. They were at time regarded as "analog students", so for you to belong, you have to use it and effectively too. This invariable has affected their academic activities since according to Schulz, Scholar and Skiera (2014) students spend on average more than two hours a day on facebook. This implies that both male and female students in the university agree that the use of social media influence students' academic performance.

\section{Conclusion:-}

The findings show that students agree that use of social media influence student's academic performance in Enugu State University of Science Technology (ESUT). The mean rating of female and male students did not differ significantly due to their general acceptance that the use of social media influence academic performance of students. This is an indication that the use of social media by students in Enugu States University of Science and Technology influence their academic performance.

\section{Recommendations:-}

Based on the findings of the study the following recommendations were made:

1. Students should be encouraged to spend more time on academic work rather than social media.

2. Universities should provide entertainment and amusement centres to keep students out from addiction to social media.

3. Students should be encouraged to watch highly informational programmes and documentaries to increase their knowledge.

4. Seminars should be organized for students to use internet services for academic activities and not only for chatting, facebook and surfing.

5. Banning the use of cell phone in classroom. 


\section{References:-}

1. Business Dictionary www.businessdictionary.com/socialmedia.html Retrieved 18/10/2016

2. Facebook Statistics (2016). More people use face book in Nigeria than elsewhere in Africa. Q2com>morepeople-use-facebook-in-Nigeria. Retrieved 18/10/2016.

3. Hinzo, O, Skiera B, Barrot, C \&Beckers, J.U. (2011). Seeding strategies for viral marketing: An empirical comparism. Journal of Marketing 75, 55-71.

4. Jacobsen, W. \&Forste, R. (2011). The wired generation: Academic and social outcome of electronic media use among university students. Cyperpschology, behavior and social networking 13(5) 309 - 320.

5. Junco, R. (2012). Too much facebook and not enough books: The relationship between frequency of facebook use, participation in facebook activities and student engagement in reading. Computer and Education Journal 58(1), 162-171

6. Kirschner, P.A. \&Aryn, C.K (2010).Facebook and academic performance.Computers \& Human behavior 26(6), $1237-1245$.

7. Schulz, C, Scholar, L \&Sikiera B. (2014). Not all fun and games: Viral marketing for utilitarian product. American Marketing Association Journal (AMA Journal) 78(1) 1-19.

8. Scott, J. (2000). Social networking analysis: A handbook. UK. Sage publications limited. www.amazon.com>socialnetworking.

9. Thompson F.T. \& Austin, W.P. (2003). Television viewing and academic achievement revisited. https:1/2/5512-school/libraryadminandadvocacy-94.

10. Woolfolk, A. (2007). Educational psychology (10th edition). Boston, MA: Allyn\& Bacon. 